\title{
Mesothelioma: Do asbestos and carbon nanotubes pose the same health risk?
}

\author{
Marie-Claude F Jaurand*1,2, Annie Renier ${ }^{1,2}$ and Julien Daubriac ${ }^{1,2}$
}

\author{
Address: ${ }^{1}$ INSERM, U674, Fondation Jean Dausset - CEPH, Paris, F-75010, France and ${ }^{2}$ Université Paris 7, Paris, F-75013, France \\ Email: Marie-Claude F Jaurand* - jaurand@cephb.fr; Annie Renier - renier@cephb.fr; Julien Daubriac - daubriac@cephb.fr \\ * Corresponding author
}

Published: 12 June 2009

Particle and Fibre Toxicology 2009, 6:16 doi:10.1186/1743-8977-6-16
Received: 28 February 2009

Accepted: 12 June 2009

This article is available from: http://www.particleandfibretoxicology.com/content/6/1/16

(C) 2009 Jaurand et al; licensee BioMed Central Ltd.

This is an Open Access article distributed under the terms of the Creative Commons Attribution License (http://creativecommons.org/licenses/by/2.0), which permits unrestricted use, distribution, and reproduction in any medium, provided the original work is properly cited.

\begin{abstract}
Carbon nanotubes (CNTs), the product of new technology, may be used in a wide range of applications. Because they present similarities to asbestos fibres in terms of their shape and size, it is legitimate to raise the question of their safety for human health. Recent animal and cellular studies suggest that CNTs elicit tissue and cell responses similar to those observed with asbestos fibres, which increases concern about the adverse biological effects of CNTs. While asbestos fibres' mechanisms of action are not fully understood, sufficient results are available to develop hypotheses about the significant factors underlying their damaging effects. This review will summarize the current state of knowledge about the biological effects of CNTs and will discuss to what extent they present similarities to those of asbestos fibres. Finally, the characteristics of asbestos known to be associated with toxicity will be analyzed to address the possible impact of CNTs.
\end{abstract}

\section{Introduction}

Carbon nanotubes (CNTs) have unique chemical and physical characteristics as a result of their nanostructure. CNTs may be used in a wide range of applications, in fields as diverse as electronics and medicine $[1,2]$. Due to their widespread use, it is important to determine the safety of CNTs for the protection of ecological systems and human health. Research to investigate the biological effects of CNTs is advancing today in order to foresee and prevent their potentially harmful effects. CNTs have fibrelike characteristics in terms of their elongated shape, dimensions and aspect ratio. As particles with at least one dimension of less than $100 \mathrm{~nm}$, they correspond to High Aspect Ratio Nanoparticles (HARN) [3]. In light of the health impact of mineral fibres, especially the fibrogenic and carcinogenic potency of asbestos fibres, and the health and socio-economical tragedies caused by unregu- lated asbestos utilization, the increasing development and uses of CNTs have triggered concern about their potential toxicity [4-8].

In recent years, several publications have reported the effects of CNTs. Most studies have concerned animal and cell responses, focusing primarily on respiratory diseases, especially the inflammatory effects in the lung. However, while inhalation is one important probable route of contamination, it must be kept in mind that there are other relevant routes of exposure. A severe primary cancer, malignant mesothelioma (MM), has been closely linked to asbestos exposure $[9,10]$. Epidemiological and animal studies have shown that asbestos fibres are not the only fibres to be associated with a risk of $\mathrm{MM}$ development. Epidemiological studies have demonstrated a higher incidence of MM in populations exposed to asbestiform and 
non-asbestos fibres [11-14]. Some manmade vitreous fibres have caused MM in animal experiments [15]. The question of whether CNTs might potentially be linked to MM development justifies further research in this area. Moreover, on the basis of the literature, CNTs have already shown effects in animals and in cell systems that are similar to those observed with asbestos fibres $[1,2,5,7]$. Two recent studies showed the occurrence of MM in genetically-modified cancer-sensitized mice and in conventional Fischer 344 rats exposed to CNTs by intraperitoneal or intrascrotal administration respectively $[16,17]$. These initial results underline the urgent need for information to further our knowledge about CNTs' potential to cause MM.

MM is a primary tumour of the serosas caused by the neoplastic transformation of mesothelial cells. In populations exposed to asbestos fibres, MM mainly occurs in the pleura, and to a lesser extent in the peritoneum and pericardium. MM is considered to be highly specific to asbestos exposure, and is found in from $60 \%$ to over $80 \%$ of cases [18-23]. In France, the calculated risk of MM attributable to occupational asbestos exposure was estimated at $83.2 \%$ (95\% CI 76.8 to 89.6 ) in men, and $38.4 \%$ (95\% CI 26.8 to 50.0) in women [24]. Many studies carried out to investigate pleural and mesothelial cell response to asbestos fibres have made it possible to reach sound hypotheses about the mechanism of action of asbestos fibres in neoplastic mesothelial cell transformation.

The aim of the present review is to explore whether our knowledge of the mechanism of action of asbestos fibres could offer a useful paradigm to provide a warning or predict the risk of CNTs, to interpret data on animal and cellular responses, and to evaluate their potential health effects. For the purposes of our discussion, we consider three points: (i) the fate of asbestos fibres following exposure; (ii) their effects on mesothelial cells and the biological mechanism associated with the cell response; (iii) the nature of the fibre parameters involved in the harmful effects, and their similarities with CNT characteristics. We begin with a summary of current knowledge on the toxicology of CNTs, then look at asbestos fibres' mechanisms of action, focusing on carcinogenic effects at the pleural level. Finally, we address the similarities between asbestos and CNTs.

\section{Toxicology of CNTs}

\section{Context of toxicological studies on CNT}

Various kinds of CNTS have been the focus of toxicological studies. CNTs are heterogeneous in terms of their structure, impurities and physico-chemical properties. Both single-walled (SWCNTs) and multi-walled (MWCNTs) CNTs have been examined in toxicological studies, including commercial and laboratory-made CNTs, whether purified or used as produced. The effects of CNTs have been investigated following in vivo exposure of rodents, and on several types of cells in culture. Most studies concerned pulmonary toxicity $[1,2,5]$. Animal experiments mainly focused on inflammatory responses after exposure by intratracheal instillation or aspiration, or intraperitoneal injection. In vitro cell systems with several types of mammalian cells have been used to study inflammatory responses and genotoxicity. A few in vivo and in vitro studies were related to dermal toxicity, and some in vitro studies focused on neurons [2]. Toxicity test systems on procaryotes were also used to assess genotoxicity. Here our focus will be on respiratory effects.

\section{Biological effects of CNTs Translocation}

Biodistribution of CNTs after deposition in the lung or via other routes has been poorly investigated. A translocation of SWCNTs in various organs has been reported by several authors [25-29]. In a recent study, MWCNTs deposited by intratracheal instillation in rats revealed clearance due to macrophage uptake and the lymphatic system without evidence of crossing the pulmonary barrier, six months after instillation [29]. It can be noted that macrophage and lymphatic clearance was also demonstrated following administration or exposure to asbestos fibres [30-33]. Erdely et al. [30] suggest that the release of soluble inflammatory factors could circulate to the vascular blood compartment after lung deposition of CNTs. The release of circulating factors must be taken into consideration to account for fibre effects. While asbestos fibres have been detected in the pleura, soluble molecules could also account for the pleural response [34], and genotoxicity may be due to clastogenic factors [35,36]. Additional studies are needed to determine the pharmacokinetics of CNTs. Regarding the numerous varieties of CNTs associated with a broad scale of physical and physico-chemical properties, fundamental studies will be necessary to establish the parameters leading the translocation process.

\section{Biological effects on mesothelial cells}

In vivo effects on mesothelial cells

Six recently-published studies concerned CNTs' effects on mesothelial cells. Three reported findings from animal experiments and three from cell system studies. One animal experiment concerned the mesothelial cell inflammatory response and pathological changes after intraperitoneal injection [37]. The authors exposed C57Bl/6 mice to four samples of MWCNTs of different sizes and aggregation states. There was one sample of "short" MWCNTs (from NanoLab, Inc; mean diameter: $14.8 \pm 0.5 \mathrm{~nm}$; mean length: 1-5 $\mu \mathrm{m}$ ); two samples of "long" MWCNTs (Long1, from Mitsui \& Co.; mean diameter: $84.9 \pm 1.9$ nm; mean length: $40-50 \mu \mathrm{m}$ [24\% > $15 \mu \mathrm{m}$ of length]; Long2 from Univ. Manchester; mean diameter: $165 \pm 4.7$ 
nm; mean length: $20-100 \mu \mathrm{m}$ [84\% > $15 \mu \mathrm{m}$ of length]); and one sample of more tangled MWCNTs (from NanoLab, Inc.; mean diameter: $10.4 \pm 0.3 \mathrm{~nm}$; mean length: 5-20 $\mu \mathrm{m}$ ), as well as carbon black. At the same time, two samples of amosite fibres were tested; these were short fibres $(4.5 \%>15 \mu \mathrm{m}$ of length) and long fibres (50.4\% > $15 \mu \mathrm{m}$ of length) known to be differently pathogenic in rodents. In prior experiments, inhalation and intraperitoneal exposure in rats to long amosite fibres revealed greater pathogenicity than short fibres in terms of fibrosis and cancer [38,39]. In the study reported by Poland et al. [37], inflammation was assessed after injection of $50 \mu \mathrm{g}$ of MWCNTs/mouse, after $24 \mathrm{~h}$ and seven days. The end points were quantification of inflammation in peritoneal lavage and histology of diaphragm. Only long samples of MWCNTs and of amosite produced inflammation and granulomas. Histological analyses revealed the occurrence of "frustrated phagocytosis" by macrophages. These results thus demonstrated some similarities between the responses to the long forms of amosite and MWCNTs. Several of the effects of asbestos were also found with CNTs. There were higher inflammatory responses with samples of long fibres. Only the samples that contained long fibres caused granulomas and "frustrated phagocytosis".

A long-term study was performed by Takagi et al. [17] who inoculated MWCNTs (MWCNTs-7 from Mitsui; diameter: $100 \mathrm{~nm}$; length: $27 \%>5 \mu \mathrm{m}$ ) in the peritoneal cavity of $\mathrm{C} 57 \mathrm{Bl} / 6 \mathrm{p} 53^{+/-}$mice. Because these mice have a mutation in one allele of the Trp53 gene, they are prone to develop cancer. Crocidolite fibres were inoculated as positive control. Mesotheliomas were found after exposure to both MWCNTs and crocidolite. This study has been discussed on several points, including concern about the type of mice, inappropriate exposure methods, high exposure dose, underestimation of the number of particles of MWCNTs and poorly-illustrated histology [40,41]. Details can be found in the different papers but some of the authors' replies can be summarized here. It is recognized that Trp53+/- mice are more prone to develop cancers, and that the response using high doses by the intraperitoneal route of exposure provides different information regarding hazard potency. However, spontaneous excess of mesotheliomas has not been reported in this type of mice, and the injection method is applicable to the hazard approach for mesothelial cells in the absence of human data. Concerning the dose, the authors mentioned that other experiments using lower doses are in progress, giving similar responses [40]. More recently, MWCNTs-7 were administered by a single intrascrotal injection in 7 Fischer 344 rats $(240 \mu \mathrm{g} / \mathrm{rat})$ maintained for an observation period of 52 weeks [16]. Dimensions were $82 \%$ of the MWCNTs with a diameter between 70-110 nm, and $72.5 \%$ between $1-4 \mu \mathrm{m}$ in length. Five vehicle-treated controls and 7 UICC crocidolite-treated rats $(470 \mu \mathrm{g} / \mathrm{rat})$ were also studied. The overall incidence of mesotheliomas was $86 \%$ in MWCNT-treated rats while no mesothelioma was found in vehicle- or crocidolite-treated rats. This method of exposure of mesothelial cells is not usually used to assess a carcinogenic potency of fibres. However, injury at the scrotal mesothelium is used as a method to investigate the repair mechanism of peritoneal mesothelium $[42,43]$. Further data are clearly needed to improve our knowledge of the effects of these MWCNTs on mesothelial cells in vivo.

\section{Effects on mesothelial cells in vitro}

To the best of our knowledge, four studies have reported in vitro effects on mesothelial cells. DNA breakage and DNA repair were found in both human normal and malignant mesothelial cells exposed to SWCNTs, as well as cell activation via AP-1, NF- $\mathrm{BB}$ and Akt [44]. Another study concluded that there was alteration of cell viability and decreased cell proliferation in human mesothelioma cells exposed to SWCNTs [45]. Three studies reported cytotoxicity on human normal mesothelial cells, malignant mesothelioma cell line, and on largeTSV40-transformed mesothelial cells (Met-5A) [44,46,47]. It is noteworthy that the same raw CNT material with different degrees of dispersion exerted different cytotoxicity on a human mesothelioma cell line [47]. In this study, the toxicity of CNT-bundles (well-dispersed material with a bundle diameter of around $20 \mathrm{~nm}$ ) was less than that of CNTagglomerates (densely roped aggregates with a rope diameter in the micron-range). CNTs appear to be taken up by different cell types and diverse in vitro effects have been associated with CNTs uptake $[2,45]$. However, the cellular uptake of CNTs is controversial. Both absence and significant uptake have been reported, as recently discussed [1]. Uptake is likely dependent on interactions between cellular receptors and cell surface functions, and CNTs surface reactivity. A variety of cell surface functions may be found, depending on the cell type. CNTs may also carry diverse reactive groups. Different sorts of chemicals and biological molecules are currently used to disperse CNTs that may modify the CNTs surface. Hence cell-CNT interactions are dependent on a number of intrinsic and extrinsic parameters. It should be recalled that modification of the surface of asbestos fibres modulates the cell responses [48-52]. In macrophages, the scavenger receptor with collagenous structure (MARCO) seems to play an important role in pulmonary damage induced by inorganic particles [53] and may be involved in interaction between MWCNTs and plasma membrane of macrophages [54]. In mesothelial cells, integrin receptors were reported to interact with asbestos fibres [50,55]. Recently, no particle internalisation was evidenced in largeTSV40-transformed mesothelial cells (MeT-5A) exposed to MWCNTs, despite cytotoxicity [46]. Further studies are necessary to clarify 
these controversial results, as fibre internalisation is an important process accounting for the adverse cellular effects of particles, and more data are needed to determine the interactions of CNT with mesothelial cells.

Biological effects in other systems

Inflammation

Several studies have investigated the inflammatory response provoked by CNT exposure, conducted on mice or rats exposed via intratracheal instillation or inhalation. Several reviews may be consulted for more details $[1,2,4-8]$. Some recent data are summarized in Table 1[30,56-59].

Regarding the large applications of CNTs and the known adverse effects of fine particulate matter, the potential effects of CNTs have also been investigated on systems other than respiratory $[1,2]$. A recent study suggests that deposition of both SWCNTs and MWCNTs produce a sys-

Table I: Summary of recent in vivo experiments carried out with CNTs

\begin{tabular}{|c|c|c|c|}
\hline Type of CNT & System & Summary results & Reference \\
\hline $\begin{array}{l}\text { SWCNTs } \\
\text { (Carbon nanotech Inc. Tx). } \\
\varnothing: 0.8-1.2 \mathrm{~nm} \\
\mathrm{~L}: 0.1-\mathrm{I} \mu \mathrm{m}\end{array}$ & $\begin{array}{l}\text { Pharyngeal deposition in } \mathrm{C} 57 \mathrm{BI} / 6 \text { mice lung ( } 40 \\
\mu g / \text { mouse). Observation } 4 \text { hours post exposure. }\end{array}$ & $\begin{array}{l}\text { Gene expression in lung and blood: } \\
\text { Upregulation of genes involved in } \\
\text { inflammation, oxidative stress, coagulation, } \\
\text { tissue remodeling. Increased percentage of } \\
\text { polymorphonuclear leucocytes (PMN) in } \\
\text { blood and bronchoalveolar lavage (BAL). }\end{array}$ & {$[30]$} \\
\hline
\end{tabular}

\section{SWCNTs.}

$240 \mathrm{~nm}$

(mode, aerodynamic diameter; in

number)

\section{$4.2 \mu \mathrm{m}$}

(mode, aerodynamic diameter; in mass)
Inhalation (4 days) in mice $-5 \mathrm{mg} / \mathrm{m}^{3}$

Short and mean term responses ( $I, 7,28$ days)

Laryngeal deposition ( $10 \mu \mathrm{g} /$ mouse).

Short and mean term responses ( $1,7,28$ days)
Lung analysis: Inflammation - Granulomas Fibrosis - Mutation of K-ras
Lung analysis: Inflammation - Granulomas Fibrosis -

No mutation of K-ras. Lower effects compared to inhalation.

$\begin{array}{ll}\text { MWCNTs. } & \text { Intratracheal deposition in rats. } \\ \varnothing: 40-60 \mathrm{~nm} & \text { One to } 7 \mathrm{mg} / \mathrm{kg} \text {. Short/mean term responses } \\ \text { L: } 0.5-500 \mu \mathrm{m} & \text { (I to } 90 \text { days) }\end{array}$

MWCNTs grinded, unheated, heated to $600^{\circ} \mathrm{C}, 2400^{\circ} \mathrm{C} ; 2400^{\circ} \mathrm{C}$ then grinded.

$\varnothing:$ 20-50 nm

L: $0.7 \pm 0.07 \mu \mathrm{m}$

\section{MWCNTs.}

$\varnothing: 40-60 \mathrm{~nm}$

L:0.5-500 $\mu \mathrm{m}$

\section{MWCNTs}

(Mitsui \& Co., LDT)

$\varnothing: \cong 80 \mathrm{~nm}$

L: $10-20 \mu \mathrm{m}$
Intratracheal deposition in rats, $2 \mathrm{mg} /$ rat. Shortterm response (3 days); mean-term (60 days)
Inflammation; dose-dependent thickening of the alveolar lining

Particles still present after 3 months

Inflammation (3 days). Granulomas (60 days).

Effects of heated CNTs lower than unheated.

Grinding restored the effects.
[56]

[57] Inflammation; dose-dependent thickening of the alveolar lining Particles still present after 3 months Intratracheal deposition in rats. One to $7 \mathrm{mg} / \mathrm{kg}$. Short/mean term responses (I to 90 days)

[56] Gene expression in lung and blood:

Pharyngeal deposition in C57BI/6 mice lung (40 $\mu \mathrm{g} /$ mouse). Observation 4 hours post exposure. Upregulation of genes involved in inflammation, oxidative stress, coagulation, tissue remodeling. Increased percentage of polymorphonuclear leucocytes (PMN) in blood and bronchoalveolar lavage (BAL).

[30]

Small aggregates entering the alveolar wall Cell proliferation and thickening of alveolar

\section{MWCNTs}

Shenzhen nanotech

$\varnothing: 500 \mathrm{~nm}$;

L: $10 \mu \mathrm{m}$
Inhalation $\left(\approx 32 \mathrm{mg} / \mathrm{m}^{3}\right)$ in mice for $5,10,15$ days deposition $\approx 0.07,0.14 ; 0.24 \mu \mathrm{g} /$ mouse. Shortterm response $(8,16,24$ days) walls

Eight and 16 days: clumps deposited on lining wall of bronchi, no inflammation - 24 days: inflammation. Clumps in the alveoli destruction of alveolar structure 
temic response, which may affect the cardiovascular system [30].

\section{Genotoxicity}

Both in vivo and in vitro effects of CNTs suggest a possible genotoxic effect, related to inflammatory responses and production of reactive oxygen species, as persistent inflammation is considered to increase the carcinogenic risk [60].

In vivo, a mutation of the K-ras oncogene was observed in mice exposed to SWCNTs by inhalation, and chromosomal aberrations were detected in type II pneumocytes after intratracheal deposition of MWCNTs in mice $[58,61]$. Several in vitro studies have reported a genotoxic potency using different cell types (Table 2) [44,46,54,57,61-70]. Activation of DNA repair processes and mutagenesis of the adenine phosphoribosyl transferase gene was found in mouse embryonic stem cells [69]. Genotoxicity as assessed by the cytokinesis-block micronucleus test, was found in rat lung epithelial cells exposed to MWCNTs [57]. Micronuclei formation occurred in human epithelial cells (MCF-7) treated with MWCNTs, and a pancentrometric probe analysis demonstrated both chromosome breakage and chromosome loss [61]. DNA damage was also reported in SWCNT-treated mouse embryo fibroblasts and in CNT-treated bronchial epithelial BEAS 2B cells [63,67]. No mutation or DNA breakage was found in a FE1-Mutatrade markMouse lung epithelial cell line exposed to SWCNTs but purine oxidation was detected with the Comet assay [71].

Investigations of the mutagenic potency of MWCNTs using bacterial test systems did not reveal mutagenic activity $[72,73]$. These bacterial assays may not be fully relevant to evaluate genotoxicity of particles. Previous results with bacterial cells were generally not or only moderately positive with asbestos fibres [74].

\section{Asbestos fibres' mechanism of action The asbestos legacy}

Numerous publications on the mechanism of action of asbestos fibres have emphasized several responses associated with the mechanism of toxicity at the serosal level. They make it clear that two aspects must be considered: the biological response and the particle status. The first depends on several factors that include the fate of asbestos fibres following inhalation, i.e., their ability to reach the pleura. It is well know that deposition, clearance and translocation of fibres are dependent on biological mechanisms and partners (mucociliary transport, phagocytic cells), but also on fibre parameters, especially fibre dimensions. Short fibres are more easily internalised by macrophages than long fibres, and long fibres possibly involve "frustrated phagocytosis." The biopersistence of fibres is linked to both their dimensions and stability in the biological milieu.

\section{Fate of asbestos fibres}

Regarding industrial uses and commercial applications of asbestos fibres, the main risk of contamination is linked to the inhalation route. In general, particle deposition depends on aerodynamic considerations. Several authors have studied the mechanism of fibre deposition and retention in the lungs [75-78]. Once deposited in the lung, asbestos fibres may be translocated into different organs and tissues, including the pleura. This was demonstrated in animals following inhalation or intratracheal deposition [79], and in humans by investigation of fibre retention in different body compartments including the pleura [80-82]. A recent paper discusses the translocation pathways of asbestos fibres to the pleura [83]. Translocation appears to be due to trans-cell migration and lymphatic circulation. These authors propose that fibres deposited in the alveolar space can be translocated to the interstitium, down the gradient of physiological water absorption. This transfer is facilitated when the epithelial layer is damaged. Once in the interstitium, fibres can be distributed to different organs. Fibres can be cleared from the interstitium via the lymphatic system and enter the capillaries as inflammation increases the interstitial pressure, allowing the fibres to migrate and be distributed throughout the whole body. Therefore, fibres can reach the pleura via the capillary system and transfer through the visceral pleura. The parietal pleural has pores of relatively large diameter (about 150-200 nm), and the pleural fluid drainage goes through stomatas where particles are found to be concentrated.

Translocation of CNTs to the pleura can be assumed, as asbestos fibres are not the only particles to be translocated to this site. Migration was observed after inhalation of refractory ceramic fibres and NMVF10a fibreglass in hamsters and rats, and anthracotic areas ("black spots") containing particulate matter are present in human pleura [81,84-87]. One important point for the study of CNT toxicity is therefore to determine their ability to be distributed in the body and to reach the pleura. It is likely that the CNT aggregation state will modulate the rate of translocation. Recent experiments comparing inhalation and tracheal or pharyngeal deposition of CNTs concluded that the different effects were likely related to a difference in the dispersion and aggregation state of the CNTs $[58,59]$. It can also be assumed that the CNT pre-treatments used for particle dispersion will also influence the biodistribution of these particles. Moreover, it must be kept in mind that CNT exposure takes place via routes other than inhalation, which ought to be investigated. 
Table 2: Summary of recent in vitro experiments carried out with CNTs

\begin{tabular}{|c|c|c|c|}
\hline Type of CNT & System & Summary results & Reference \\
\hline $\begin{array}{l}\text { SWCNTs (HiPco), (CNI Inc.). } \\
\varnothing: 0.4-1.2 \mathrm{~nm} \\
\text { L: } 1-3 \mu \mathrm{m}\end{array}$ & Lung hamster fibroblasts (V79) & $\begin{array}{l}\text { Cytotoxicity (time and dose dependent) } \\
\text { DNA breakage (comet assay) } \\
\text { No significant enhancement of micronuclei }\end{array}$ & {$[62]$} \\
\hline $\begin{array}{l}\text { SWCNTs ( } 50 \% \text { SWCNT, about } 40 \% \\
\text { other nanotubes). } \\
\varnothing: \text { I.I nm, L: } 0.5-100 \mu \mathrm{m}\end{array}$ & $\begin{array}{l}\text { BEAS 2B human bronchial epithelial } \\
\text { cells }\end{array}$ & $\begin{array}{l}\text { Dose-dependent decrease in cell viability. Dose- } \\
\text { dependent DNA damage. No formation of } \\
\text { micronuclei }\end{array}$ & {$[63]$} \\
\hline $\begin{array}{l}\text { SWCNTs (NIST) } \\
\varnothing: 1.4 \mathrm{~nm}, \mathrm{~L}: 2-5 \mu \mathrm{m}\end{array}$ & $\begin{array}{l}\text { Normal human mesothelial cells and } \\
\text { human mesothelioma cell line }\end{array}$ & $\begin{array}{l}\text { Cell death. DNA lesions } \\
\text { Stress response activation }\end{array}$ & {$[44]$} \\
\hline $\begin{array}{l}\text { SWCNTs. Folate conjugated. } \\
\varnothing: \text { I-3 nm, L: } 100-200 \mathrm{~nm}\end{array}$ & HepG2 cells (express folate receptor) & $\begin{array}{l}\text { No toxicity if }<50 \mu \mathrm{g} / \mathrm{ml} \text {. Dose-dependent } \\
\text { apoptosis. Kinetics of SWCNT internalisation: Mb } \rightarrow \\
\text { cytoplasm } \rightarrow \text { extracellular }\end{array}$ & {$[64]$} \\
\hline SWCNTs (HiPco) & $\begin{array}{l}\text { Human lung epithelial cells A549 and } \\
\text { immortalised NHBE }\end{array}$ & $\begin{array}{l}\text { Decreased inflammatory response in TNF alpha- } \\
\text { stimulated cells }\end{array}$ & {$[65]$} \\
\hline $\begin{array}{l}\text { SWCNTs Mitsui \& Co., Ltd } \\
\text { Size unspecified }\end{array}$ & Human aortic endothelial cells & $\begin{array}{l}\text { Internalisation: CNTs identified in the cytoplasm. } \\
\text { Cytotoxicity. IL- } 8 \text { release. Actin filament and } \\
\text { Ecadherin disruption. Reduced tubule formation. }\end{array}$ & {$[66]$} \\
\hline SWCNTs & Mouse embryo fibroblasts & $\begin{array}{l}\text { Low cytotoxicity. DNA damage (comet assay) } \\
\text { Oxidative stress }\end{array}$ & {$[67]$} \\
\hline $\begin{array}{l}\text { MWCNTs. } \\
\varnothing: 67 \mathrm{~nm}\end{array}$ & Mouse macrophages (J774.I). & $\begin{array}{l}\text { No MAPKs activation; no apoptosis. } \\
\text { Interaction with membrane receptors (MARCO) and } \\
\text { plasma membrane destruction }\end{array}$ & {$[54]$} \\
\hline $\begin{array}{l}\text { MWCNTs. } \\
\varnothing: I 1.3 \mathrm{~nm} \\
\text { L:0.7 } \mu \mathrm{m}\end{array}$ & Human epithelial cells (MCF-7) & $\begin{array}{l}\text { Chromosomal aberrations (micronuclei) showing } \\
\text { chromosome breakage and loss of whole } \\
\text { chromosomes }\end{array}$ & {$[61]$} \\
\hline $\begin{array}{l}\text { MWCNTs (CI00, Arkema). } \\
\varnothing: 12 \mathrm{~nm} \\
\text { L: } 0.1-13 \mu \mathrm{m}\end{array}$ & $\begin{array}{l}\text { Human epithelial (A549) and Large T } \\
\text { SV40 transformed mesothelial (Met- } \\
\text { 5A) cells }\end{array}$ & $\begin{array}{l}\text { Decrease in cell viability (mitochondrial alteration) } \\
\text { without apoptosis. No oxidative stress. No } \\
\text { MWCNT internalisation }\end{array}$ & {$[46]$} \\
\hline $\begin{array}{l}\text { MWCNTs grinded, unheated, heated } \\
\text { to } 600^{\circ} \mathrm{C}, 2400^{\circ} \mathrm{C} ; 2400^{\circ} \mathrm{C} \text { then } \\
\text { grinded. } \\
\varnothing: 20-50 \mathrm{~nm} ; \mathrm{L}: 0.7 \pm 0.07 \mu \mathrm{m}\end{array}$ & Rat lung epithelial cells. & $\begin{array}{l}\text { Chromosomal aberrations (micronuclei) } \\
\text { Lower effects with } 2400^{\circ} \mathrm{C} \text { sample in comparison to } \\
600^{\circ} \mathrm{C} \text { and unheated }\end{array}$ & {$[57]$} \\
\hline $\begin{array}{l}\text { MWCNTs. } \\
\varnothing: 100-200 \mathrm{~nm}, \mathrm{~L}: \mathrm{a} \text { few } \mu \mathrm{m}\end{array}$ & Human epithelial cells (A549) & $\begin{array}{l}\text { DNA breakage (comets). } \\
\text { No oxidative DNA lesions }\end{array}$ & {$[68]$} \\
\hline $\begin{array}{l}\text { MWCNTs } \\
\text { (Tsinghua \& Nananfeng, Cine) }\end{array}$ & Mouse embryonic cells (ES) & $\begin{array}{l}\text { P53 activation. Induction of DNA repair. } \\
\text { Mutations (adenine phosphoribosyl transferase) }\end{array}$ & {$[69]$} \\
\hline $\begin{array}{l}\text { MWCNTs Mitsui \& Co., Ltd } \\
\text { Size unspecified }\end{array}$ & Human aortic endothelial cells & $\begin{array}{l}\text { Cytotoxicity. IL-8 release. Actin filament and } \\
\text { Ecadherin disruption. Reduced tubule formation. }\end{array}$ & {$[66]$} \\
\hline MWCNTs & Human pneumocytes A549 & $\begin{array}{l}\text { Decrease in cell viability } \\
\text { Internalisation }\end{array}$ & {$[70]$} \\
\hline
\end{tabular}




\section{Biological and genomic effects of asbestos fibres on mesothelial cells \\ Inflammation and mesothelial cell activation}

Many authors have described the inflammatory processes occurring in the lung and in the pleura, and shown that fibres can interact with mesothelial cells in culture conditions. Fibre deposition in the lung is followed by the recruitment of inflammatory cells, which produce several factors: ROS (reactive oxygen species), RNS (reactive nitrogen species), clastogenic factors and cytokines that may stimulate and/or damage neighbouring mesothelial cells. Fibres also may produce ROS. Moreover, mesothelial cells respond by fibre internalisation according to a phagocytic process associated with oxidative reactions [34,88-93].

In this situation, mesothelial cells adapt to the oxidative environment by oxidative stress, increasing oxidant defences and decreasing natural ROS and RNS production. At the same time, several regulatory pathways are activated: signalling pathways (MAPKs) associated with cell proliferation and apoptosis, and DNA repair and control of cell cycle progression in response to DNA damage $[94,95]$. These different reactions are the consequence of 2 types of interactions: between cells (inflammatory cells/ mesothelial cells) and between cells and fibres. As neoplastic transformation is linked to genetic damage and requires proliferation steps, comparison between the genotoxic effects of asbestos and CNTs might provide clues making it possible to develop hypotheses about the potential effects of CNTs.

\section{Genotoxicity}

Many investigations have focused on DNA damage provoked by asbestos fibres in mesothelial cells. Several studies have demonstrated different types of DNA damage (DNA breakage, base oxidation), and perturbation of the mitotic process $[94,95]$, showing that base oxidation and DNA breakage (single strand and double strand breaks) were detected in asbestos-treated mesothelial cells [95-
100]. These may be due to ROS/RNS production and to the mesothelial cells' ability to phagocytise asbestos fibres. Fibre uptake does not abolish the mitotic process as some fibres are found in dividing mesothelial cells. Moreover, extensive chromosome damage was described. A list of chromosome abnormalities has been reported by different authors. Asbestos fibres produce structural chromosome alterations; significant enhancement of aneuploid cells, abnormal anaphases and telophases [101-105]. Induction of micronuclei by all types of asbestos in primary cultures of human mesothelial cells has been reported by Poser et al. [106]. Other studies have shown genomic alterations in asbestos-treated human mesothelial cells. Loss of heterozygosity was detected as asbestosinduced mutations in a human mesothelioma cell line [107]. Using 3D reconstruction, Cortez et al. recently reported mitotic abnormalities, centrosome amplification and aneuploid cell formation in lung carcinoma cells, even with long periods of recovery post-treatment [108]. These findings are similar to earlier reports concerning rat pleural mesothelial cells and using less powerful methods.

\section{Gene expression in asbestos-treated mesothelial cells}

A few studies have investigated gene expression in asbestos-treated mesothelial cells using microarray analysis (Table 3) [109-111]. They confirmed results obtained in studies focusing on given types of damages. Modulation of several biological processes were observed. They were associated with inflammatory, proliferation, DNA repair and cell adhesion pathways. Further studies comparing the cell response to CNTs and to the different types of asbestos fibres are likely to be informative in order to approach the possible effects of CNTs.

\section{Gene alterations in mesothelioma}

Epidemiological studies have shown that $\mathrm{MM}$ is a consequence of asbestos exposure in a majority of cases [18-24]. This led us to assume that genomic alterations found in MM could be linked to the effect of asbestos fibres. The

Table 3: Summary of in vitro experiments related to gene expression in crocidolite-treated mesothelial cells

\begin{tabular}{|c|c|c|}
\hline System & Summary results & Reference \\
\hline $\begin{array}{l}\text { Human mesothelial cells (LP9/TERT-I) exposed to low and high } \\
\text { concentrations ( } 15 \text { and } 75 \mu \mathrm{m}^{2} / \mathrm{cm}^{2} \text { per dish) for } 8 \text { or } 24 \mathrm{~h} \\
\text { Oligonucleotide microarray analysis }\end{array}$ & $\begin{array}{l}\text { ATF3-dependent modulation of inflammatory cytokines and } \\
\text { growth factor production }\end{array}$ & {$[109]$} \\
\hline $\begin{array}{l}\text { Human SV } 40 \text {-immortalized pleural mesothelial (MeT-5A) cells } \\
\text { exposed to I } \mu \mathrm{g} / \mathrm{cm}^{2} \text { dish for I-48 } \mathrm{h} \\
\text { Oligonucleotide microarray analysis }\end{array}$ & $\begin{array}{l}\text { I h: upregulation of nucleosome assembly, translational initiation, } \\
\text { transcription, I-kappaB kinase/NF-kappaB cascade, survival } \\
48 \text { h: downregulation of cytoskeletal anchoring, transcription, } \\
\text { survival }\end{array}$ & {$[110]$} \\
\hline $\begin{array}{l}\text { Normal rat pleural mesothelial cells exposed to } 5 \mu \mathrm{g} / \mathrm{cm}^{2} \text { dish for } \\
24 \mathrm{~h} \\
\text { Oligonucleotide microarray analysis }\end{array}$ & Induction of fra-I-linked cd44 and c-met expression & {$[111]$} \\
\hline
\end{tabular}


identification of these changes can provide insight into the molecular mechanism of action of asbestos on mesothelial cells. MM cells exhibit frequent alterations in tumour suppressor genes found at the INK4 locus, and often the type of alteration is deletions. NF2 is another frequently inactivated tumour suppressor gene in MM cells. Germinal mutations in NF2 are responsible for type 2 neurofibromatosis, but NF2 patients are not prone to develop mesothelioma. TP53 is mutated less often in MM cells.

To investigate whether genetic alterations in mesothelioma might be relevant to the effect of asbestos fibres, animal models of human MM are developed. Mesotheliomas develop following exposure, by intraperitoneal injection, of hemizygous NF2 mice to asbestos fibres [112,113]. This made it possible to compare characteristics of mouse and human mesotheliomas.

Histologically, very similar tumours were observed, and the genomic alterations in the tumour suppressor genes investigated were very close to those observed in human MM. These gene are involved in the control of cell cycle and junction stability. Regarding the function of the gene, it might be of interest to determine the consequences of CNT exposure on cell cycle progression and cell architecture.

\section{Asbestos fibre characteristics related to disease} If one looks at fibre parameters, several features appear to be shared by CNTs and asbestos fibres. To compare CNTs and asbestos fibres in relation to toxic potential, we should focus on the asbestos characteristics modulating asbestos toxicity. Shape, size, chemistry and surface reactivity are all related to cell and tissue responses to asbestos fibres.

\section{Shape}

CNTs have a thin and elongated shape compatible with a fibre, according to the WHO fibre definition of a particle with parallel edges and an aspect ratio (length/diameter) greater than three. It seems that CNTs are prone to form aggregates, ropes and clumps, a feature that is not fully similar to asbestos, which forms bundles of rather wellorganized structures. The length of CNTs may vary, reaching up to several micrometers or longer $[7,114]$. Accordingly, "frustrated phagocytosis" was observed in cells engulfing long CNTs [37].

\section{Size}

The diameters of asbestos fibres fall in the nanosize range. If one refers to the dimensions of the UICC samples, which have been used in a number of animal and cell studies, the diameter of chrysotile fibres was less than about $100 \mathrm{~nm}$, and $200 \mathrm{~nm}$ for crocidolite. Length depended on the sample, but generally averaged several micrometers. However, there was a significant range in length and a small percentage of fibres longer than $10 \mu \mathrm{m}$ were generally present.

\section{Chemistry}

Metals are considered to be important elements to account for fibre toxicity. Iron content, either structural or as contaminant, may be linked to the formation of ROS and RNS. Depending on the method of production, CNTs may contain metals as contaminants; moreover, they can be functionalized to acquire specific properties. Data in the literature show a wide qualitative and quantitative diversity of metal contaminants in the chemical composition of CNT samples, emphasizing the importance of using well-defined samples for toxicological analyses [7].

\section{Surface reactivity}

Surface reactivity is an important parameter in asbestosrelated effects. The production of ROS and RNS was mentioned above. It is interesting to note that some studies indicate that, in contrast to asbestos, CNTs quench ROS in an acellular system generating hydroxyl radicals [115]. While asbestos fibres are hydrophilic, CNTs, unless functionalized, are hydrophobic. As a result, CNTs are often treated with dispersing agents prior to exposing cells or animals to CNTs suspended in aqueous medium.

Asbestos fibres' ability to adsorb biological molecules is another fibre parameter to take into consideration. Asbestos adsorbs proteins and phospholipids, which has consequences on cell-fibre interactions. An enhancement of biological effects can be observed (particle internalisation, cytotoxicity), as well as a reduction of toxicity [116119].

Asbestos bodies are structures found in the lung of asbestos-exposed subjects. They consist of an asbestos fibre core surrounded by a complex coat produced by the cell and tissue reaction; they are made of apatite mineralization and protein aggregation (hemosiderin, ferritin). These structures are more likely formed on amphiboles rather than on chrysotile. They are not specific to asbestos, as they have been reported in other fibrous and non-fibrous particles. It would be of interest to know whether these structures could be formed on CNTs [120-122].

\section{Biopersistence}

While biopersistence is not an intrinsic particle parameter, it has received attention for the evaluation of the carcinogenic potency of manmade vitreous fibres (MMVFs) $[123,124]$. Biopersistence in the lung is the result of a clearance mechanism and the behaviour of fibres in the biological medium. Clearance depends on particle uptake by scavenger cells; it is then modulated by the fibre size 
and toxicity (short particles are eliminated following uptake by macrophages; cytotoxic particles impair the process). The behaviour of the fibres is also size-dependent (fibre dimensions govern the mechanism and site of deposition in the lung), as well as dependent on the fibre structure and chemistry (these parameters modulate the stability of the particles in the biological medium). Some chemical elements may dissolve and reduce fibre strength, breaking the fibres into smaller fragments. Finally, biopersistence modulates the amount of fibre retained in the lung and the time it remains in the lung. To date, CNTs have been considered biopersistent, but further studies are needed to determine the relevance of this parameter in the context of human exposure to CNTs [57].

\section{Discussion}

CNTs are valuable industrial products with multiple applications in the field of nanotechnologies, yet legitimate concerns about their potential adverse effects on human health need to be addressed. The risk of $M M$, a primary pleural carcinoma linked to asbestos exposure, must be examined in light of the physical nature of CNTs, which are elongated and ultrafine, and the fact that human beings may be exposed to CNTs through inhalation. While not yet definitive, data are now available providing information on the pulmonary and cellular effects of CNTs, which may be compared to those of asbestos fibres. Moreover, the asbestos fibre characteristics involved in the toxic processes may be compared to those of CNTs to determine their similarities. These comparisons make it possible to develop hypotheses about common and different mechanisms of action. A summary of comparisons between CNTs and asbestos is provided in Tables 4 and 5.

A paradigm for the health effects of HARN has emerged from toxicology studies of industrial fibres, including asbestos. A recent report reviewed state-of-the-art knowledge of the toxicity of asbestos and HARN [3]. This clearly suggest a community of toxicological features and concern between HARN of different origin and composition.
The reader will find in this quoted review additional information on other HARN (nanowires, nanorods) and the proposal for a research strategy to determine the potential toxicity of HARN.

\section{Shape, structure and chemistry}

Both CNTs and asbestos particles share fibrous morphology, and their dimensions are in the same range. CNTs are manufactured in two main forms, SWCNTs and MWCNTs. A SWCNT is a single-layer graphene sheet rolled up in a cylindrical shape, whereas a MWCNT contains several layers [125]. The structure of chrysotile presents similarities with MWCNT. CNT samples may have much higher length than asbestos fibrils and form clumps resulting in different presentation and tissue penetration. One role of CNT sample dispersion to modulate biological effects is suggested by the results reported from in vivo experiments studying inhalation and intratracheal deposition.

\section{Biodistribution}

Similarly to asbestos fibres, CNTs may be deposited and retained in the lung after inhalation. So far, there is no definitive data on their migration and long-term retention, and on their translocation to the pleura. Interaction with mesothelial cells is likely important to account for asbestos pathogenicity; however, distant effects after deposition in the lung have been reported. As already mentioned, CNTs are the subject of scientific interest for a large number of already mature or potential applications. One paradox is that biological studies with CNTs are designed to investigate both adverse (exposure to toxic dust) and beneficial (nanomedicine) effects. These different types of studies show that MWCNTs are concentrated in the lymph nodes after deposition in the lung, and that functionalized MWCNTs also accumulate in lymph nodes after subcutaneous injection $[29,126]$. CNT biodistribution has been studied following intraperitoneal or intravenous injection in mice. CNTs are distributed throughout the entire body and cleared via urine excretion. McDevitt et al. found an accumulation of labelled SWCNTs in the kidney, liver, spleen and, to a lesser extent, in bone [127].

Table 4: Comparison between physical and chemical parameters of asbestos and CNTs

\begin{tabular}{ll}
\hline Parameter & Comparison \\
\hline Shape & Both are elongated particles; fibre shaped. \\
\hline Dimensions & Asbestos fibre diameter: range of $100 \mathrm{~nm}$. Chrysotile fibrils: $\cong 50 \mathrm{~nm}$ of diameter. Same order as MWCNTs. \\
\hline Structure & $\begin{array}{l}\text { Chrysotile: multi-layered rolled sheets of brucite }\left(\mathrm{MgOH}_{2}\right) \text { and silicon oxide }\left(\mathrm{SiO}_{2}\right) \text {. Important aggregation with CNTs, which } \\
\text { may form more entangled bundles, ropes, than asbestos. }\end{array}$ \\
\hline Chemistry & Different chemistry. Possibility of metal impurities in both asbestos and CNTs. \\
\hline Surface reactivity & Both show sorptive properties to biological molecules. ROS production: no definitive answer for CNTs. \\
\hline
\end{tabular}


Table 5: Comparison between biological effects of asbestos and CNTs

\begin{tabular}{ll}
\hline Cell/tissue response & Comparison \\
\hline Particle uptake & $\begin{array}{l}\text { Demonstrated with both types. Conflicting results with CNTs. Exocytosis found with CNTs, so far not } \\
\text { investigated with asbestos. }\end{array}$ \\
\hline Cytotoxicity & Both cytotoxic. \\
\hline DNA damage, mutation, gene interaction & Found with both asbestos and CNTs. \\
\hline Transfection & Gene transfer is with asbestos. CNT gene knockdown. \\
\hline Biodistribution & Both types are cleared via the lymphatic system and found in different organs \\
\hline Inflammation, granulomas, fibrosis & $\begin{array}{l}\text { Found with both asbestos and CNTs. Both types show dependence of biological effects with fibre } \\
\text { dimensions: bioactivity of long fibres. }\end{array}$ \\
\hline Cancer & MM found with both asbestos and CNTs by peritoneal exposure. \\
\hline
\end{tabular}

There is to date no reason to exclude the possibility of CNT translocation to the serosa.

In a recent paper, Hankin et al. [128] summarized the research required into the mechanism of translocation of nanoparticles across the respiratory epithelium, and the resulting possible effects in and beyond the lung. The authors provide recommendations to develop research on translocation and penetration of nanoparticles that take into consideration the parameters allowing a robust interpretation of the data.

\section{The relationship between structure and biological effects} Based on our present knowledge, a comparison between cell responses to SWCNTs and MWCNTs cannot be established. This is partly due to the limited number of investigations carried out with both types of nanotubes in the same assays. Nevertheless, both types are able to induce biological responses in one or several cell types, and in the lung. While studying the biodistribution of MWCNTs following intraperitoneal injection, Guo et al. compared different results obtained with both SWCNTs and MWCNTs [129]. These authors suggest that toxic responses observed in the kidney in some studies may depend on whether CNTs are functionalized, a procedure that may improve the biocompatibility.

Surface functionalization, purity and treatment of CNTs appear to modulate the biological response, as found in different studies $[115,130,131]$. The surface modifications of CNTs developed in the field of nanomedicine studies are of interest to learn about interactions between CNTs and cells or organelles. It is already known that surface changes influences cell responses. Viability of neuroblastoma cells was not affected by pure MWCNTs (99\% purity). Viability and proliferation were reduced after acid treatment or when MWCNTs of lower purity were used $(97 \%)$ [131]. Acute pulmonary toxicity and genotoxicity of MWCNTs were reduced upon heating but restored upon grinding, in relation with surface defects[57]

Studies carried out with asbestos have demonstrated that long and thin fibres are more toxic than short fibres, without excluding potential toxicity for short fibres. Limits of $4 \mu \mathrm{m}$ or $8 \mu \mathrm{m}$ in length have been proposed, mainly based on in vivo experiments. CNTs can fulfil these length criteria, and similarly to asbestos, long CNTs were more active than short CNTs [37]. More data on size-dependent biological effects of CNTs will be of great interest.

Surface reactivity of asbestos fibres has been largely advanced as a key parameter accounting for their toxicity in terms of ROS production and sorptive abilities. ROS production is associated with cytotoxicity, cell activation, and chromosome and DNA damage. Conflicting data are found with CNTs, as both production and scavenging of ROS were described. CNTs are a large family regarding their method of generation, treatment and functionalization. Hence the surface reactivity of CNTs towards biological systems will be largely dependent on the type of nanotubes. This may be maximized by treatments to disperse CNTs prior to use for biological studies. Different CNTs samples may have more heterogeneous surface activities than asbestos.

\section{Biological effects}

Available data in the literature concerning the effects of CNTs on mesothelial cells remain limited. Several effects of asbestos fibres, especially genetic damage, are related to fibre internalisation. While asbestos fibres are clearly internalized by mesothelial cells, there is no definitive data on CNT uptake by these cells. The physico-chemical 
properties of CNTs are likely to take into consideration in the occurrence of this physiological process.

Animals and cell systems exposed to CNTs appear to develop several responses similar to those observed with asbestos. There is some evidence that CNTs produce inflammation and mesothelioma when inoculated in the peritoneal cavity of mice. This result is consistent with inflammatory potency after inhalation or intratracheal instillation. Several CNT-exposed mammalian cells respond in culture conditions by inflammatory reactions and oxidative stress. Genotoxic potency has been reported in different cell types, including mesothelial cells, as well as in studies conducted in vivo. Hence CNTs used in experimental systems fulfil several criteria to elicit tissue injury, including the mesothelium.

\section{Conclusion}

The link between asbestos effects and mesothelioma has been attributed to several mechanisms. This link has been investigated using different animal models and cell types, and substantial similarities exist in the responses of the different cell types. Several fibre properties have been linked to adverse effects. Shape, dimension and surface reactivity are all important parameters. Reactive species may produce DNA lesions (base oxidation, breaks); their origin is related both to fibre surface reactivity and phagocytosis. Inflammation contributes to the production of ROS/RNS. Chromosome damage appears to be of major importance to account for the significant effects of asbestos. Gene deletions and recombinations might result from these effects. Integrity of some cell processes may be critical in the response to asbestos: dynamics of the cell membrane (fibre uptake, cell division) and control of cell division (check points, chromosome segregation processes, repair of DNA breakage, cytokinesis). In view of findings of a much less hazard of short than some long/ non-biopersistent HARN, more information is needed on the CNTs' characteristics and conditions to which we may be exposed. Based on available data in the literature and knowledge of the mechanisms of action of asbestos fibres, it appears that CNTs may elicit responses that are similar to those caused by asbestos fibres.

In this review, for the sake of brevity, CNTs have been considered as a single entity. However, there is a large degree of heterogeneity within the CNT family. The legacy of our knowledge on the mechanism of action of asbestos prompts us to recognize some similarities between these two types of particles. Nevertheless, in view of the diverse uses of CNTs, toxicological studies should be carried out in the context of the respective applications, taking into consideration the possible interactions between the target tissue and the nanotubes, and their possible biodistribution. An evaluation of the conditions and type of exposure to CNTs thus appears mandatory to focus clearly on the safety and health issues. Exposure by inhalation for aerosolized CNTs must take into consideration both lung and pleural diseases.

\section{Competing interests}

The authors declare that they have no competing interests.

\section{Authors' contributions}

MCJ contributed to the design and drafting of the manuscript. AR participated in the acquisition of data on asbestos on mesothelial cells and the genetics of mesothelioma cells. JD analysed the data in the literature on gene expression.

\section{Acknowledgements}

The authors would like to thank Audrey Saint-Albin for her help in editing the manuscript.

\section{References}

I. Shvedova AA, Kisin ER, Porter D, Schulte P, Kagan VE, Fadeel B, Castranova $V$ : Mechanisms of pulmonary toxicity and medical applications of carbon nanotubes: Two faces of janus? Pharmacol Ther 2009, 1 21:192-204.

2. Helland A, Wick P, Koehler A, Schmid K, Som C: Reviewing the environmental and human health knowledge base of carbon nanotubes. Environ Health Perspect 2007, I I 5: I I25- I I 3 I.

3. Tran CL, Hankin SM, Ross B, Aitken RJ, Jones AD, Donaldson K, Stone V, Trantra R: An outline scoping study to determine whether high aspect ratio nanoparticles (harn) should raise the same concerns as do asbestos fibres. Report on project CB0406 2008 [http://www.safenano.org/Uploads/HARN.pdf].

4. Stern ST, McNeil SE: Nanotechnology safety concerns revisited. Toxicol Sci 2008, 1 0 I:4-21.

5. Kolosnjaj J, Szwarc H, Moussa F: Toxicity studies of carbon nanotubes. Adv Exp Med Biol 2007, 620:18I-204.

6. Boczkowski J, Lanone S: Potential uses of carbon nanotubes in the medical field: How worried should patients be? Nanomed 2007, 2:407-4I0.

7. Donaldson K, Aitken R, Tran L, Stone V, Duffin R, Forrest G, Alexan$\operatorname{der} A$ : Carbon nanotubes: $A$ review of their properties in relation to pulmonary toxicology and workplace safety. Toxicol Sci 2006, 92:5-22.

8. Bergamaschi E, Bussolati O, Magrini A, Bottini M, Migliore L, Bellucci $S$, lavicoli I, Bergamaschi A: Nanomaterials and lung toxicity: Interactions with airways cells and relevance for occupational health risk assessment. Int J Immunopathol Pharmacol 2006, 19:3-10.

9. Bianchi C, Bianchi T: Malignant mesothelioma: Global incidence and relationship with asbestos. Ind Health 2007, 45:379-387.

10. Wagner JC, Sleggs CA, Marchand P: Diffuse pleural mesothelioma and asbestos exposure in the north western cape province. $\mathrm{Br} J$ Ind Med 1960, 17:260-27I.

II. Whitehouse AC, Black CB, Heppe MS, Ruckdeschel J, Levin SM: Environmental exposure to libby asbestos and mesotheliomas. Am J Ind Med 2008, 5 I:877-880.

12. Dikensoy O: Mesothelioma due to environmental exposure to erionite in turkey. Curr Opin Pulm Med 2008, 14:322-325.

13. Comba P, Gianfagna A, Paoletti L: Pleural mesothelioma cases in biancavilla are related to a new fluoro-edenite fibrous amphibole. Arch Environ Health 2003, 58:229-232.

14. Baris I, Simonato L, Artvinli M, Pooley F, Saracci R, Skidmore J, Wagner C: Epidemiological and environmental evidence of the health effects of exposure to erionite fibres: A four-year study in the cappadocian region of turkey. Int J Cancer 1987, 39:10-17.

15. IARC: Man-made mineral fibres. IARC Monographs on the Evaluation of Carcinogenic Risks to Humans 2002, 81: I-38I. 
16. Sakamoto $Y$, Nakae D, Fukumori N, Tayama K, Maekawa A, Imai K, Hirose A, Nishimura T, Ohashi N, Ogata A: Induction of mesothelioma by a single intrascrotal administration of multi-wall carbon nanotube in intact male fischer $\mathbf{3 4 4}$ rats. J Toxicol $\mathrm{Sc}$ 2009, 34:65-76.

17. Takagi A, Hirose A, Nishimura T, Fukumori N, Ogata A, Ohashi N, Kitajima S, Kanno J: Induction of mesothelioma in p53 +/mouse by intraperitoneal application of multi-wall carbon nanotube. J Toxicol Sci 2008, 33:105-II6.

18. Albin M, Magnani C, Krstev S, Rapiti E, Shefer I: Asbestos and cancer: An overview of current trends in europe. Environ Health Perspect 1999, 107(Suppl 2):289-298.

19. Kishimoto T: Cancer due to asbestos exposure. Chest 1992, 101:58-63.

20. Kishimoto T, Ozaki S, Kato K, Nishi H, Genba K: Malignant pleural mesothelioma in parts of japan in relationship to asbestos exposure. Ind Health 2004, 42:435-439.

21. Mowe G, Gylseth B: Occupational exposure and regional variation of malignant mesothelioma in norway, 1970-79. Am J Ind Med 1986, 9:323-332.

22. Park EK, Hannaford-Turner KM, Hyland RA, Johnson AR, Yates DH: Asbestos-related occupational lung diseases in nsw, australia and potential exposure of the general population. Ind Health 2008, 46:535-540.

23. Yeung $P$, Rogers $A$ : An occupation-industry matrix analysis of mesothelioma cases in australia 1980-1985. Appl Occup Environ Hyg 200I, 16:40-44.

24. Goldberg M, Imbernon E, Rolland P, Gilg Soit Ilg A, Saves M, de Quillacq A, Frenay C, Chamming's S, Arveux P, Boutin C, Launoy G, Pairon JC, Astoul P, Galateau-Sallé F, Brochard P: The french national mesothelioma surveillance program. Occup Environ Med 2006 63:390-395

25. McDevitt MR, Chattopadhyay D, Kappel BJ, Jaggi JS, Schiffman SR, Antczak C, Niardarson JT, Brentjens R, Scheinberg DA: Tumor targeting with antibody-functionalized, radiolabeled carbon nanotubes. J Nucl Med 2007, 48: I I80-1 I89.

26. Cherukuri P, Gannon C], Leeuw TK, Schmidt HK, Smalley RE, Curley SA, Weisman RB: Mammalian pharmacokinetics of carbon nanotubes using intrinsic near-infrared fluorescence. Proc Natl Acad Sci USA 2006, 103:18882-18886.

27. Singh R, Pantarotto D, Lacerda L, Pastorin G, Klumpp C, Prato M, Bianco A, Kostarelos K: Tissue biodistribution and blood clearance rates of intravenously administered carbon nanotube radiotracers. Proc Natl Acad Sci USA 2006, 103:3357-3362.

28. Wang H, Wang J, Deng X, Sun H, Shi Z, Gu Z, Liu Y, Zhao Y: Biodistribution of carbon single-wall carbon nanotubes in mice. $J$ Nanosci Nanotechnol 2004, 4: $1019-1024$

29. Elgrabli D, Floriani M, Abella-Gallart S, Meunier L, Gamez C, Delalain P, Rogerieux F, Boczkowski J, Lacroix G: Biodistribution and clearance of instilled carbon nanotubes in rat lung. Part Fibre Toxicol 2008, 5:20.

30. Erdely A, Hulderman T, Salmen R, Liston A, Zeidler-Erdely PC, Schwegler-Berry D, Castranova V, Koyama S, Kim YA, Endo M, Simeonova PP: Cross-talk between lung and systemic circulation during carbon nanotube respiratory exposure. Potential biomarkers. Nano Lett 2009, 9:36-43.

3I. Oberdörster G, Morrow PE, Spurny K: Size dependent lymphatic short term clearance of amosite fibers in the lung. Ann Occup Hyg 1988, 32:149-156.

32. Trosic I, Matausic-PisI M, Hors N: Pathways and quantification of insoluble particles in the lung compartments of the rat. Int Hyg Environ Health 2000, 203:39-43.

33. Dodson RF, Williams MG, Corn CJ, Brollo A, Bianchi C: Asbestos content of lung tissue, lymph nodes, and pleural plaques from former shipyard workers. Am Rev Respir Dis 1990, I 42:843-847.

34. Adamson IYR, Bakowska J: Kgf and hgf are growth factors for mesothelial cells in pleural lavage fluid after intratracheal asbestos. Exp Lung Res 200I, 27:605-616.

35. Brooks AL: Evidence for 'bystander effects' in vivo. Hum Exp Toxicol 2004, 23:67-70.

36. Emerit I: Reactive oxygen species, chromosome mutation, and cancer - possible role of clastogenic factors in carcinogenesis. Free Rad Biol Med 1994, 16:99-109.

37. Poland CA, Duffin R, Kinloch I, Maynard A, Wallace WA, Seaton A, Stone V, Brown S, Macnee W, Donaldson K: Carbon nanotubes introduced into the abdominal cavity of mice show asbestoslike pathogenicity in a pilot study. Nat Nanotechnol 2008, 3:423-428.

38. Donaldson K, Brown GM, Brown DM, Bolton RE, Davis JM: Inflammation generating potential of long and short fibre amosite asbestos samples. Br J Ind Med 1989, 46:27I-276.

39. Davis JM, Addison J, Boltob RE, Donaldson K, Jones AD, Smith T: The pathogenicity of long versus short fibre samples of amosite asbestos administered to rats by inahlation and intraperitoneal injection. BrJ Exp Pathol. 1986, 67(3):4I5-430.

40. Ichihara G, Castranova V, Tanioka A, Miyazawa K: Re: Induction of mesothelioma in p53 +/- mouse by intraperitoneal application of multi-wall carbon nanotube. J Toxicol Sci 2008, 33:38I-382.

4l. Donaldson K, Stone V, Seaton A, Tran L, Aitken R, Poland C: $\mathbf{R e}$ Induction of mesothelioma in p53 +/- mouse by intraperitoneal application of multi-wall carbon nanotube. J Toxicol Sci. 2008, 33(3):385.

42. Foley-Comer AJ, Herrick SE, Al-Mishlab T, Prele CM, Laurent GJ, Mutsaers SE: Evidence for incorporation of free-floating mesothelial cells as a mechanism of serosal healing. J Cell Sci 2002, I I5:1383-1389.

43. Mutsaers SE, Whitaker D, Papadimitriou JM: Mesothelial regeneration is not dependent on subserosal cells. J Pathol 2000, 190:86-92.

44. Pacurari M, Yin XJ, Zhao J, Ding M, Leonard SS, Schwegler-Berry D, Ducatman BS, Sbarra D, Hoover MD, Castranova V, Vallyathan V: Raw single-wall carbon nanotubes induce oxidative stress and activate mapks, ap-I, nf-kappab, and akt in normal and malignant human mesothelial cells. Environ Health Perspect 2008, I16:1211-1217.

45. Kaiser JP, Wick P, Manser P, Spohn P, Bruinink A: Single walled carbon nanotubes (swcnt) affect cell physiology and cell architecture. I Mater Sci Mater Med 2008, 19:1523-1527.

46. Tabet L, Bussy C, Amara N, Setyan A, Grodet A, Rossi MJ, Pairon JC, Boczkowski J, Lanone S: Adverse effects of industrial multiwalled carbon nanotubes on human pulmonary cells. J Toxicol Environ Health A 2009, 72:60-73.

47. Wick P, Manser P, Limbach LK, Dettlaff-Weglikowska U, Krumeich F, Roth S, Stark W], Bruinink $A$ : The degree and kind of agglomeration affect carbon nanotube cytotoxicity. Toxicol Lett 2007, 168: $121-13 \mid$

48. Wu J, Liu W, Koenig K, Idell S, Broaddus VC: Vitronectin adsorption to chrysotile asbestos increases fiber phagocytosis and toxicity for mesothelial cells. Am J Physiol Lung Cell Mol Physiol 2000, 279:L916-L923.

49. Donaldson K, Hill IM, Beswick PH: Superoxide anion release by alveolar macrophages exposed to respirable industrial fibres: Modifying effect of fibre opsonisation. Exp Toxicol Pathol 1995, 47:229-231.

50. Boylan AM, Sanan DA, Sheppard D, Broaddus VC: Vitronectin enhances internalization of crocidolite asbestos by rabbit pleural mesothelial cells via the integrin avb5. I Clin Invest 1995, 96: | 987-2001.

51. Lu J, Keane MJ, Ong T, Wallace WE: In vitro genotoxicity studies of chrysotile asbestos fibers dispersed in simulated pulmonary surfactant. Mutat Res 1994, 320:253-259.

52. Jaurand MC, Thomassin JH, Baillif $P$, Magne L, Touray JC, Bignon J: Chemical and photoelectron spectrometry analysis of the adsorption of phospholipid model membranes and red blood cell membranes on to chrysotile fibres. $\mathrm{Br} J$ Ind Med 1980 , 37:169-174.

53. Thakur SA, Hamilton R Jr, Pikkarainen T, Holian A: Differential binding of inorganic particles to marco. Toxicol Sci 2009 , 107:238-246.

54. Hirano S, Kanno S, Furuyama A: Multi-walled carbon nanotubes injure the plasma membrane of macrophages. Toxicol Appl Pharmacol 2008, 232:244-25I.

55. Pande $P$, Mosleh TA, Aust AE: Role of alphavbeta5 integrin receptor in endocytosis of crocidolite and its effect on intracellular glutathione levels in human lung epithelial (a549) cells. Toxicol Appl Pharmacol 2006, 21 0:70-77.

56. Liu A, Sun K, Yang J, Zhao D: Toxicological effects of multi-wall carbon nanotubes in rats. J Nanopart Res 2008, 10:1303-1307.

57. Muller J, Huaux F, Fonseca A, Nagy JB, Moreau N, Delos M, Raymundo-Pinero E, Beguin F, Kirsch-Volders M, Fenoglio I, Fubini B, 
Lison D: Structural defects play a major role in the acute lung toxicity of multiwall carbon nanotubes: Toxicological aspects. Chem Res Toxicol 2008, 2 I:1698-I705.

58. Shvedova AA, Kisin E, Murray AR, Johnson VJ, Gorelik O, Arepalli S, Hubbs AF, Mercer RR, Keohavong P, Sussman N, Jin J, Yin J, Stone S, Chen BT, Deye G, Maynard A, Castranova V, Baron PA, Kagan VE: Inhalation vs. Aspiration of single-walled carbon nanotubes in c57b//6 mice: Inflammation, fibrosis, oxidative stress, and mutagenesis. Am J Physiol Lung Cell Mol Physiol 2008, 295:L552-565.

59. Li JG, Li WX, Xu JY, Cai XQ, Liu RL, Li YJ, Zhao QF, Li QN: Comparative study of pathological lesions induced by multiwalled carbon nanotubes in lungs of mice by intratracheal instillation and inhalation. Environ Toxicol 2007, 22:4I5-42I.

60. Federico A, Morgillo F, Tuccillo C, Ciardiello F, Loguercio C: Chronic inflammation and oxidative stress in human carcinogenesis. Int J Cancer 2007, 121:238I-2386.

6I. Muller J, Decordier I, Hoet PH, Lombaert N, Thomassen L, Huaux F, Lison D, Kirsch-Volders M: Clastogenic and aneugenic effects of multi-wall carbon nanotubes in epithelial cells. Carcinogenesis 2008, 29:427-433.

62. Kisin ER, Murray AR, Keane MJ, Shi XC, Schwegler-Berry D, Gorelik O, Arepalli S, Castranova V, Wallace WE, Kagan VE, Shvedova AA: Single-walled carbon nanotubes: Geno- and cytotoxic effects in lung fibroblast v79 cells. J Toxicol Environ Health A 2007, 70:207I-2079

63. Lindberg HK, Falck GC, Suhonen S, Vippola M, Vanhala E, Catalan J, Savolainen K, Norppa H: Genotoxicity of nanomaterials: DNA damage and micronuclei induced by carbon nanotubes and graphite nanofibres in human bronchial epithelial cells in vitro. Toxicol Lett 2008, 186:166-173.

64. Kang B, Yu D, Chang S, Chen D, Dai Y, Ding Y: Intracellular uptake, trafficking and subcellular distribution of folate conjugated single walled carbon naotubes within living cells. Nanotechnology 2008, 19:375103.

65. Herzog E, Byrne HJ, Casey A, Davoren M, Lenz AG, Maier KL, Duschl $A$, Oostingh G]: Swcnt suppress inflammatory mediator responses in human lung epithelium in vitro. Toxicol Appl Pharmacol 2009, 234:378-390.

66. Walker VG, Li Z, Hulderman T, Schwegler-Berry D, Kashon ML, Simeonova PP: Potential in vitro effects of carbon nanotubes on human aortic endothelial cells. Toxicol Appl Pharmacol 2009, 236:319-328.

67. Yang H, Liu C, Yang D, Zhang H, Xi Z: Comparative study of cytotoxicity, oxidative stress and genotoxicity induced by four typical nanomaterials: The role of particle size, shape and composition. J Appl Toxicol 2009, 29:69-78.

68. Karlsson HL, Cronholm P, Gustafsson J, Moller L: Copper oxide nanoparticles are highly toxic: A comparison between metal oxide nanoparticles and carbon nanotubes. Chem Res Toxicol 2008, 21:1726-1732

69. Zhu L, Chang DW, Dai L, Hong Y: DNA damage induced by multiwalled carbon nanotubes in mouse embryonic stem cells. Nano Lett 2007, 7:3592-3597.

70. Simon-Deckers A, Gouget B, Mayne-L'hermite M, Herlin-Boime N, Reynaud C, Carriere M: In vitro investigation of oxide nanoparticle and carbon nanotube toxicity and intracellular accumulation in a549 human pneumocytes. Toxicology 2008, 253:137-146.

7I. Jacobsen NR, Pojana G, White P, Moller P, Cohn CA, Korsholm KS, Vogel U, Marcomini A, Loft S, Wallin H: Genotoxicity, cytotoxicity, and reactive oxygen species induced by single-walled carbon nanotubes and $c(60)$ fullerenes in the fel-mutatrade markmouse lung epithelial cells. Environ Mol Mutagen 2008, 49:476-487.

72. Di Sotto A, Chiaretti M, Carru GA, Bellucci S, Mazzanti G: Multiwalled carbon nanotubes: Lack of mutagenic activity in the bacterial reverse mutation assay. Toxicol Lett 2009, 184:192-197.

73. Wirnitzer U, Herbold B, Voetz M, Ragot J: Studies on the in vitro genotoxicity of baytubes( $(r))$, agglomerates of engineered multi-walled carbon-nanotubes (mwcnt). Toxicol Lett 2008, 186:160-165.

74. Jaurand MC: Use of in-vitro genotoxicity and cell transformation assays to evaluate potential carcinogenicity of fibres. Mechanisms in fiber carcinogenesis 1996:55-72.
75. Oberdorster G: Toxicokinetics and effects of fibrous and nonfibrous particles. Inhal Toxicol 2002, I 4:29-56.

76. Lippmann M, Yeates DB, Albert RE: Deposition, retention and clearance of inhaled particles. $\mathrm{Br} J$ Ind Med. 1980 37(4):337-362.

77. Morgan A: Deposition of inhaled asbestos and man-made mineral fibres in the respiratory tract. Ann Occup Hyg 1995, 39:747-758

78. Morgan I, Evans JC, Evans RJ, Hounam RF, Holmes A, Doyle SG: Studies on the deposition of inhaled fibrous material in the respiratory tract of the rat and its subsequent clearance using radioactive tracer techniques. li. Deposition of the uicc standard reference samples of asbestos. Environ Res 1975, 10:196-207.

79. Lippmann M: Deposition and retention of inhaled fibres: Effects on incidence of lung cancer and mesothelioma. Occup Environ Med 1994, 5 I:793-798.

80. Paoletti L, Falchi M, Batisti D, Zappa M, Chellini E, Biancalani M Characterization of asbestos fibers in pleural tissue from 21 cases of mesothelioma. Med Lav 1993, 84:373-378.

8I. Boutin C, Dumortier P, Rey F, Viallat JR, Devuyst P: Black spots concentrate oncogenic asbestos fibers in the parietal pleura: Thoracoscopic and mineralogic study. Am J Respir Crit Care Med. 1996, 153(1):444-449.

82. Tossavainen A, Karjalainen A, Karhunen PJ: Retention of asbestos fibers in the human body. Environ Health Perspect. 1994 102(Suppl 5):253-255

83. Miserocchi GA, Sancini GA, Mantegazza F, Chiappino G: Translocation pathways for inhaled asbestos fibers. Environ Health 2008, 7:4.

84. Bermudez E, Mangum JB, Moss OR, Wong BA, Everitt Jl: Pleura dosimetry and pathobiological responses in rats and hamsters exposed subchronically to $\mathrm{mmvf} \mathrm{IOa}$ fiberglass. Toxicol Sci 2003, 74: I65-I73.

85. Gelzleichter TR, Bermudez E, Mangum JB, Wong BA, Janszen DB, Moss OR, Everitt Jl: Comparison of pulmonary and pleural responses of rats and hamsters to inhales refractory ceramic fibers. Toxicol Sciences 1999, 49:93-101.

86. Everitt JI, Gelzleichter TR, Bermudez E, Mangum JB, Wong BA, Janszen DB, Moss OR: Comparison of pleural responses of rats and hamsters to subchronic inhalation of refractory ceramic fibers. Environ Health Perspect 1997, 105(Suppl 5): I209-1213.

87. Mitchev K, Dumortier P, De Vuyst P: 'black spots' and hyaline pleural plaques on the parietal pleura of 150 urban necropsy cases. Am / Surg Pathol 2002, 26: I 198-1206.

88. Manning CB, Vallyathan V, Mossman BT: Diseases caused by asbestos: Mechanisms of injury and disease development. Int Immunopharmacol 2002, 2: 19|-200.

89. Vallyathan V, Mega JF, Shi XL, Dalal NS: Enhanced generation of free radicals from phagocytes induced by mineral dusts. Am J Respir Cell Mol Biol 1992, 6:404-4I3.

90. Antony VB, Sahn SA, Mossman BT, Gail DB, Kalica A: Pleural cell biology in health and disease. Am Rev Respir Dis. 1992, I45(5): I 236-I 239

91. Kane AB: Mechanisms of mineral fibre carcinogenesis. larc sci Pub 1996: II-34.

92. Shukla A, Gulumian M, Hei TK, Kamp D, Rahman Q, Mossman BT: Multiple roles of oxidants in the pathogenesis of asbestosinduced diseases. Free Radic Biol Med 2003, 34: I I 17- I I 29.

93. Bhattacharya K, Dopp E, Kakkar P, Jaffery FN, Schiffmann D, Jaurand MC, Rahman I, Rahman Q: Biomarkers in risk assessment of asbestos exposure. Mutat Res 2005, 579:6-2I.

94. Upadhyay D, Kamp DW: Asbestos-induced pulmonary toxicity: Role of DNA damage and apoptosis. Exp Biol Med (Maywood) 2003, 228:650-659.

95. Jaurand MC: Mechanisms of fiber-induced genotoxicity. Environ Health Perspect 1997, 105:1073-1084.

96. Nygren J, Suhonen S, Norppa H, Linnainmaa K: DNA damage in bronchial epithelial and mesothelial cells with and without associated crocidolite asbestos fibers. Environ Mol Mutagen 2004, 44:477-482.

97. Unfried K, Schürkes C, Abel J: Distinct spectrum of mutations induced by crocidolite asbestos: Clue for 8-hydroxydeoxyguanosine-dependent mutagenesis in vivo. Cancer Res 2002, 62:99-104. 
98. Burmeister B, Schwerdtle T, Poser I, Hoffmann E, Hartwig A, Muller WU, Rettenmeier AW, Seemayer NH, Dopp E: Effects of asbestos on initiation of DNA damage, induction of DNA-strand breaks, p53-expression and apoptosis in primary, sv40-transformed and malignant human mesothelial cells. Mutat Res 2004, 558:81-92.

99. Liu W, Ernst JD, Broaddus VC: Phagocytosis of crocidolite asbestos induces oxidative stress, DNA damage, and apoptosis in mesothelial cells. Am J Respir cell Mol Biol 2000, 23:37I-378.

100. Levresse V, Renier A, Levy F, Broaddus VC, Jaurand MC: DNA breakage in asbestos-treated normal and transformed (tsv40) rat pleural mesothelial cells. Mutagenesis 2000, I 5:239-244.

I0I. Pelin K, Hirvonen A, Taavitsainen M, Linanainmaa K: Cytogenetic response to asbestos fibers in cultured human primary mesothelial cells from 10 different donors. Mutat Res 1995, 334:225-233.

102. Pelin-Enlund K, Husgafvel-Pursiainen K, Tammilehto, Klockars M, Jantunen K, Gerwin BI, Harris CC, Tuomi T, Vanhala E, Mattson K, Linnainmaa K: Asbestos-related malignant mesothelioma: Growth, cytology, tumorigenicity and consistent chromosome findings in cell lines from five patients. Carcinogenesis 1990, I 1:673-681.

103. Wang NS, Jaurand MC, Magne L, Kheuang L, Pinchon MC, Bignon J: The interactions between asbestos fibers and metaphase chromosomes of rat pleural mesothelial cells in culture. A scanning and transmission electron microscopic study. Am J Pathol 1987, I 26:343-349.

104. Jaurand MC, Kheuang L, Magne L, Bignon J: Chromosomal changes induced by chrysotile fibres or benzo(3-4)pyrene in rat pleural mesothelial cells. Mutat Res 1986, 169:|4|-|48.

105. Lechner JF, Tokiwa T, LaVeck M, Benedict WF, Banks-Schlegel S, Yeager H, Barnerjee A, Harris CC: Asbestos-associated chromosomal changes in human mesothelial cells. Proc Natl Acad Sci USA 1985, 82:3884-3888.

106. Poser I, Rahman Q, Lohani M, Yadav S, Becker HH, Weiss DG, Schiffmann D, Dopp E: Modulation of genotoxic effects in asbestosexposed primary human mesothelial cells by radical scavengers, metal chelators and a glutathione precursor. Mutat Res 2004, 559:19-27.

107. Both K, Turner DR, Henderson DW: Loss of heterozygosity in asbestos-induced mutations in a human mesothelioma cell line. Environ Mol Mutagen. 1995, 26(I):67-7I

108. Cortez BA, Machadosantelli GM: Chrysotile effects on human lung cell carcinoma in culture: 3 -d reconstruction and DNA quantification by image analysis. BMC Cancer 2008, 8: I8I.

109. Shukla A, Macpherson MB, Hillegass J, Ramos-Nino ME, Alexeeva V, Vacek PM, Bond JP, Pass HI, Steele C, Mossman BT: Alterations in gene expression in human mesothelial cells correlate with mineral pathogenicity. Am J Respir Cell Mol Biol. 2008, 4I(I): II4-I23.

I 10. Nymark P, Lindholm PM, Korpela MV, Lahti L, Ruosaari S, Kaski S, Hollmen J, Anttila S, Kinnula VL, Knuutila S: Gene expression profiles in asbestos-exposed epithelial and mesothelial lung cell lines. BMC Genomics 2007, 8:62.

I I I. Ramos-Nino ME, Scapoli L, Martinelli M, Land S, Mossman BT: Microarray analysis and rna silencing link fra-I to cd44 and c-met expression in mesothelioma. Cancer Res 2003, 63:3539-3545.

112. Altomare DA, Vaslet CA, Skele KL, De Rienzo A, Devarajan K, Jhanwar SC, McClatchey Al, Kane AB, Testa JR: A mouse model recapitulating molecular features of human mesothelioma. Cancer Res 2005, 65:8090-8095.

113. Fleury-Feith J, Lecomte C, Renier A, Matrat M, Kheuang L, Abramowski V, Levy F, Janin A, Giovannini M, Jaurand MC: Hemizygosity of $\mathrm{nf} 2$ is associated with increased susceptibility to asbestos-induced peritoneal tumours. Oncogene 2003, 22:3799-3805.

I 14. Bianco A, Kostarelos K, Prato M: Opportunities and challenges of carbon-based nanomaterials for cancer therapy. Expert Opin Drug Deliv 2008, 5:33|-342.

I I5. Fenoglio I, Greco G, Tomatis M, Muller J, Raymundo-Pinero E, Beguin F, Fonseca A, Nagy JB, Lison D, Fubini B: Structural defects play a major role in the acute lung toxicity of multiwall carbon nanotubes: Physicochemical aspects. Chem Res Toxicol 2008, 21:1690-1697
I16. Chang MJ, Joseph LB, Stephens RE, Hart RW: Modulation of biological processes by mineral fiber adsorption of macromolecules in vitro. J Environ Pathol Toxicol Oncol 1990, 10:89-93.

II7. Donaldson K, Li XY, Dogra S, Miller BG, Brown GM: Asbestosstimulated tumor necrosis factor release from alveolar macrophages depends on fibre length and opsonization. J Pathol 1992, I 68:243-248.

I 18. Scheule RK, Holian A: Modification of asbestos bioactivity for the alveolar macrophage by selective protein adsorption. Am J Respir Cell Mol Biol 1990, 2:44 I-448.

119. Fubini B: Surface reactivity in the pathogenic response to particulates. Environ health Perspect 1997, 1 05:1013-1020.

120. Churg A, Warnock ML, Green N: Analysis of the cores of ferruginous (asbestos) bodies from the general population. li. True asbestos bodies and pseudoasbestos bodies. Lab Invest 1979, 40:31-38.

12I. Dumortier P, Coplü L, Broucke I, Emri S, Selcuk T, de Maertelaer V, de Vuyst P, Baris I: Erionite bodies and fibres in bronchoalveolar lavage fluid (balf) of residents from tuzköy, cappadocia, turkey. Occup Environ Med 200I, 58:26I-266.

122. Gaensler EA, Addington WW: Asbestos or ferruginous bodies. $N$ Engl J Med 1969, 280:488-492.

123. Donaldson K, Tran CL: An introduction to the short-term toxicology of respirable industrial fibres. Mutat Res 2004, 553:5-9.

124. Oberdorster G: Determinants of the pathogenicity of manmade vitreous fibers (mmvf). Int Arch Occup Environ Health 2000 , 73(Suppl):S60-68.

125. Ju-Nam Y, Lead JR: Manufactured nanoparticles: An overview of their chemistry, interactions and potential environmental implications. Sci Total Environ 2008, 400:396-4I4.

126. Yang F, Hu J, Yang D, Long J, Luo G, Jin C, Yu X, Xu J, Wang C, Ni Q, Fu D: Pilot study of targeting magnetic carbon nanotubes to lymph nodes. Nanomed 2009, 4:317-330.

127. McDevitt MR, Chattopadhyay D, Jaggi JS, Finn RD, Zanzonico PB, Villa C, Rey D, Mendenhall J, Batt CA, Njardarson JT, Scheinberg DA: Pet imaging of soluble yttrium-86-labeled carbon nanotubes in mice. PLOS ONE 2007, 2(9):e907.

128. Hankin SM, Tran CL, Ross B, Donaldson K, Stone V, Q C: Cell pen: A study to identify the physico-chemical factors controlling the capacity of nanoparticles to penetrate cells. Project CBN047 2008 [http://www.safenano.org/Admin/Uploads/ CellPenCB0407.pdf].

129. Guo J, Zhang X, Li Q, Li W: Biodistribution of functionalized multiwall carbon nanotubes in mice. Nucl Med Biol 2007, 34:579-583.

130. Muller J, Huaux F, Moreau N, Misson P, Heilier JF, Delos M, Arras M, Fonseca A, Nagy JB, Lison D: Respiratory toxicity of multi-wall carbon nanotubes. Toxicol Appl Pharmacol 2005, 207:22 I-23I.

131. Vittorio $O$, Raffa $V$, Cuschieri $A$ : Influence of purity and surface oxidation on cytotoxicity of multi-wall carbon nanotubes with human neuroblastoma cells. Nanomedicine 2009 in press.

Publish with Bio Med Central and every scientist can read your work free of charge

"BioMed Central will be the most significant development for disseminating the results of biomedical research in our lifetime. "

Sir Paul Nurse, Cancer Research UK

Your research papers will be:

- available free of charge to the entire biomedical community

- peer reviewed and published immediately upon acceptance

- cited in PubMed and archived on PubMed Central

- yours - you keep the copyright 